\title{
Giant right atrial myxoma and ovarian formation: a case report
}

\author{
CPetra Bulić*, \\ CKoraljka Benko, \\ 구Tamara Hlača Caput, \\ DDavorka Lulić, \\ (1)Sanja Matijević \\ Rončević, \\ - Saša Matulić, \\ - Lea Skorup Ćutić, \\ Olvana Grgić Romić, \\ DAlen Ružić, \\ - Luka Zaputović, \\ -Teodora Zaninović \\ Jurjević
}

University of Rijeka, Faculty of Medicine, University Hospital Centre Rijeka, Rijeka, Croatia

\section{RECEIVED:}

March 28, 2021

ACCEPTED:

April 2, 2021

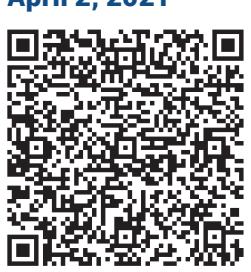

\author{
KEYWORDS: myxoma, ovarian formation, right atrium. \\ CITATION: Cardiol Croat. 2021;16(5-6):206. | https://doi.org/10.15836/ccar2021.206
}

*ADDRESS FOR CORRESPONDENCE: Petra Bulić, Klinički bolnički centar Rijeka, Tome Strižića 3, HR-51000 Rijeka, Croatia. / Phone: +385-51-407-225 / E-mail: petra.bulic9@gmail.com

ORCID: Petra Bulić, https://orcid.org/0000-0002-5219-1836 • Koraljka Benko, https://orcid.org/0000-0001-7556-0860 Tamara Hlača Caput, https://orcid.org/0000-0002-7749-0031 • Davorka Lulić, https://orcid.org/0000-0002-8937-437X Sanja Matijević Rončević, https://orcid.org/0000-0003-0627-2114 • Lea Skorup Ćutić, https://orcid.org/0000-0003-2246-0908 Ivana Grgić Romić, https://orcid.org/0000-0002-0035-4445 • Alen Ružić, https://orcid.org/0000-0001-5031-2975

Luka Zaputović, https://orcid.org/0000-0001-9415-9618 • Teodora Zaninović Jurjević, https://orcid.org/0000-0001-8359-3910

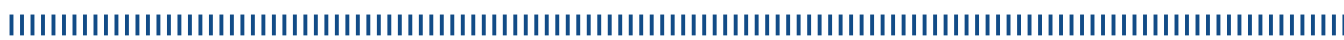

Introduction: Myxomas are the most common benign cardiac tumors. ${ }^{1}$ In $75 \%$ of cases, myxomas are located in the left atrium, usually connected to the interatrial septum by a stalk..$^{1,2}$ The frequency of myxomas in the right atrium varies from $10-20 \%{ }^{1,2}$ They are often clinically silent or cause unspecific symptoms like dyspnea, weight loss, leg swelling, fatigue, palpitations or paraneoplastic syndrome, which is why they are often diagnosed after they've grown large in size. ${ }^{1,3}$ Right atrial myxomas may have serious repercussions such as embolization of tumor fragments to pulmonary circulation or functional tricuspid stenosis by obstructing tricuspid valve, causing syncope, symptoms of right ventricular failure and even sudden cardiac death., ${ }^{1,2}$

Case report: 70 -years-old woman presented to the Emergency department with lower abdominal pain persisting for the last 10 days. An abdominal ultrasound was performed and verified hepatomegaly with dilated hepatic veins, ascites and a formation of the right ovary with retroperitoneal lymphadenopathy. It also found large right atrial mass which is why the patient was referred to the Cardiology Department. Echocardiogram showed giant tumorous mass in the right atrium, measuring $10 x 6 \mathrm{~cm}$ in diameter, attached to interatrial septum and protruding into the right ventricle through the tricuspid valve in diastole. Due to the formation of the right ovary, gynecological diagnostic work up was performed. The patient's case was presented in Gynecological/Heart Team expertise meeting and the patient was referred to surgery and underwent simultaneous bilateral adnexectomy and right atrial tumor excision. Pathohistological results confirmed diagnosis of myxoma, while analysis of ovarian formation is still in progress. Our patient recovered well and was discharged from the hospital 10 days after surgery.

Conclusion: Due to its atypical symptoms and low incidence rate, right sided myxomas can go unnoticed for a long period of time. Giant myxoma is a rare finding, it should be treated surgically and the time to surgery should be as short as possible, since prolongation may have serious consequences on the outcome. $\square$ Cardiologia Croatica 2021;16(5-6):206.

1. European Society of Cardiology [Internet]. Cardiac tumors EACVI 3D Echocardiography Box [cited 2021, March 28]; Available from: https://www.escardio.org/Education/Practice-Tools/EACVI-toolboxes/3D-Echo/cardiac-tumors

2. Maraj S, Pressman GS, Figueredo VM. Primary cardiac tumors. Int J Cardiol. 2009 Apr 3;133(2):152-6. https://doi.org/10.1016/j.ijcard.2008.11.103

3. Reynen K. Cardiac myxomas. N Engl J Med. 1995 Dec 14;333(24):1610-7. https://doi.org/10.1056/NEJM199512143332407 